\title{
The correlation of metal content in medicinal plants and their water extracts
}

\author{
Saša S. Ranđelović, Danijela A. Kostić, Aleksandra R. Zarubica, Snežana S.Mitić, Milan N. Mitić \\ University of Niš, Faculty of Science and Mathematics, Department of Chemistry, Višegradska 33, 18000 Niš, Serbia
}

\begin{abstract}
The quality of some medicinal plants and their water extracts from southeast Serbia was determined on the basis of metal content using atomic absorption spectrometry. Two methods were used for the preparation of water extracts in order to examine the impact of the preparation on the content of metals in the samples. The contents of investigated metals in both water extracts were markedly lower than in medicinal plants, but were higher in the water extract prepared by method (I), with the exception of lead. The coefficients of extraction for the observed metal can be represented in the following order: $\mathrm{Zn}>\mathrm{Mn}>\mathrm{Pb}>\mathrm{Cu}>\mathrm{Fe}$. Correlation coefficients between the metal concentration in the extract and total metal content in plant material varied in the range from 0.6369 to 0.9956. This indicates the need for plants to be collected and grown in unpolluted areas, and to examine the metal content. The content of heavy metals in the investigated medicinal plants and their water extracts is below the maximum allowable values, so they are safe to use.
\end{abstract}

Keywords: medicinal plants, water extracts, AAS.

PROFESSIONAL PAPER

UDC 615.89:633.88(497.11):543.42:54

Hem. Ind. 67 (4) 585-591 (2013)

doi: 10.2298/HEMIND120703098R

Available online at the Journal website: http://www.ache.org.rs/HI/

Beverages and extracts prepared from medicinal plants are commonly consumed in the world for their desirable aroma, taste and putative positive physiological functions. The growing interest in plant beverages all over the world would be connected with polyphenol antioxidative activity, fighting the harmful influence of environmentally generated free radicals [1]. Medicinal plants and their extracts containing many essential and nonessential elements provided from the soil were grown. The human body requires both metallic and non-metallic elements within certain permissible limits for growth and good health (Table 1) [2]. Many elements play a vital role in the metabolic processes and in the general well-being of humans, but some can be toxic.

Heavy metals such as copper $(\mathrm{Cu})$ are essential to maintain metabolism of the human body, but at higher concentration they can lead to poisoning and can cause kidney and liver damage. Nickel (Ni) is also needed in small amounts to produce red blood cells, but at higher concentration it becomes mildly toxic. It can cause heart and liver damage. Cadmium (Cd) is associated with renal dysfunction and it may also produce bone defects such as osteoporosis. Beside copper (Cu), chromium ( $\mathrm{Cr}$ ) can be can accumulated in the kidney and liver and can cause severe damage to those systems. In

Correspondence: S.S. Randjelović, Department of Chemistry, Faculty of Science and Mathematics, University of Niš, Višegradska 33, 18000 Niš, Serbia.

E-mail: despotovicsasa@yahoo.com

Paper received: 3 July, 2012

Paper accepted: 15 October, 2012 addition, this metal can also damage the circulatory and nerve tissue. High levels of lead $(\mathrm{Pb})$ may result in toxic biochemical effects in humans, which in turn cause problems in the synthesis of hemoglobin, effects on the kidneys, gastrointestinal tract, joints and reproductive system and acute or chronic damage to the nervous system and also can cause mental retardation. Owing to the importance of metals present in medicinal plants, many studies were carried out to determine their levels in medicinal plants and their extracts. The broadest view contents of the trace element in tea leaves, made tea and tea infusion was given in a review by Karak. The presence of trace elements in all analyzed tea samples surveyed in this review was within the safe limits towards human beings, but it appeared that it still provides a significant additional source of trace elements [3].

A number of herbs grown in southeastern Serbia are used in traditional medicine. Razić et al. in their works determined the metal content in the soil, herb and herbal drags. Elemental composition of soil, of different parts of plant of Echinacea purpurea (Asteracae) and ethanolic extract were determined by flame atomic absorption and flame atomic emission spectrometry. The trace element data were evaluated by multivariate methods, i.e. principal component analysis and hierarchical cluster analysis [4]. Similar analyses were carried out for many herbs from Serbia [5-8]. Determination of heavy metal concentrations in tea samples taken from Belgrade market (Serbia) were provided, too [9]. Trace metals in medicinal plants and their extracts were determined by Kostic et al. [10]. 
Table 1. Recommended daily intakes of various minerals

\begin{tabular}{|c|c|c|}
\hline Mineral & Recommended daily intake & Over dosage \\
\hline Boron & $<20 \mathrm{mg}$ & No information found \\
\hline Calcium & $1000 \mathrm{mg}$ & Doses larger than 1500 mg may cause stomach problems for sensitive individuals \\
\hline Chlorine & 3400 mg (in chloride form) & No information found \\
\hline Chromium & $120 \mu \mathrm{g}$ & $\begin{array}{c}\text { Doses larger than } 200 \mu g \text { are toxic and may cause concentration problems } \\
\text { and fainting }\end{array}$ \\
\hline Copper & $2 \mathrm{mg}$ & As little as $10 \mathrm{mg}$ of copper can have a toxic effect \\
\hline Fluorine & $3,5 \mathrm{mg}$ & No information found \\
\hline lodine & $150 \mu \mathrm{g}$ & No information found \\
\hline Iron & $15 \mathrm{mg}$ & $\begin{array}{c}\text { Doses larger than } 20 \text { mg may cause stomach upset, constipation } \\
\text { and blackened stools }\end{array}$ \\
\hline Magnesium & $350 \mathrm{mg}$ & Doses larger than 400 mg may cause stomach problems and diarrhea \\
\hline Manganese & $5 \mathrm{mg}$ & Excess manganese may hinder iron adsorption \\
\hline Molybdenum & $75 \mu \mathrm{g}$ & Doses larger than $200 \mu \mathrm{g}$ may cause kidney problems and copper deficiencies \\
\hline Nickel & $<1 \mathrm{mg}$ & Products containing nickel may cause skin rash in case of allergies \\
\hline Phosphorus & $1000 \mathrm{mg}$ & $\begin{array}{c}\text { Contradiction: the FDA states that doses larger than } 250 \mathrm{mg} \text { may cause stomach } \\
\text { problems for sensitive individuals }\end{array}$ \\
\hline Potassium & $3500 \mathrm{mg}$ & $\begin{array}{l}\text { Large doses may cause stomach upsets, intestinal problems or } \\
\text { heart rhythm disorder }\end{array}$ \\
\hline Selenium & $35 \mu \mathrm{g}$ & Doses larger than $200 \mu \mathrm{g}$ can be toxic \\
\hline Sodium & $2400 \mathrm{mg}$ & No information found \\
\hline Vanadium & $<1,8 \mathrm{mg}$ & No information found \\
\hline Zinc & $15 \mathrm{mg}$ & Doses larger than $25 \mathrm{mg}$ may cause anaemia and copper deficiency \\
\hline
\end{tabular}

Determination of trace elements in tea is important from two aspects: a) to judge their nutritional value and $b)$ to guard against any possible ill-effects due to intake of heavy metals. The content of heavy metals is one of the criteria deciding on the acceptability of the herb material for the production of herbal beverages or the other traditional medicaments. Therefore, the control of heavy metals contents in herbs and herbal beverages is required $[11,12]$.

In this work, heavy metal contents in the following plants and their teas: Hipericum perforatum L., Saturea Montana L., Calendula officinalis L., Origanum vulgare L., Crataegus leavigata L., and Prunus spinosa L were determined. These plants have been used in traditional Serbian medicine for the treatment of many diseases.

Hipericum perforatum L. (St. John's wort) is a plant from the Hypericaceae family. It has antidepressant, sedative and antibiotic effects [13].

Saturea montana L. (Winter savory) is a plant from the Lamiaceae family. It has an extremely strong antiseptic effect, and as such is used for the treatment of respiratory and digestive organs illnesses, and the inflammations of skin and mucosa [14].

Calendula officinalis L. (Marigold) is a plant from the Asteraceae family. It has antibacterial and bactericidal effects; therefore, it is used for the treatment of wounds, psoriasis, etc. [15]. Origanum vulgare L. (Ore- gano) is a plant from the Lamiaceae family. It has antispasmodic, bronchodilating, and diuretic effects [16].

Crataegus oxyacantha L. (Hawthorn) is a plant from the Rosaceae family. It is used for the treatment of arteriosclerosis, heart diseases, and mild nervous disorders [17].

Prunus spinosa L. (Blackthorn) is a plant from the Rosaceae family. It is used for the treatment of skin problems, to alleviate stomach colic, etc. [18].

\section{EXPERIMENTAL}

\section{Reagents}

All the reagents used were of analytical purity (Merck, Germany). The working solutions were prepared immediately before the analysis from the basic solution with $1000 \mathrm{mg} / \mathrm{l}$ concentration for all metals. For the preparation of standard solutions high purity Milli-Q water was used. The glassware and polyethylene containers used for analysis were washed with tap water, then soaked over the night in $6 \mathrm{M} \mathrm{HNO}_{3}$ solution and rinsed several times with ultra-pure water to eliminate absorbance due to detergent.

\section{Apparatus}

Atomic absorption measurements were made using a Varian SpectraAA 10 with background correction and hollow cathode lamps. Air-acetylene flame was used 
for determination of all the elements. The calibration interval, wavelength, slit, and detection level are given in Table 2.

\section{Sample preparation}

The plant material was collected in the flowering phase from the natural habitats of the plants Hipericum perforatum L., Saturea Montana L., Calendula officinalis L., Origanum vulgare L. and fruit of Crataegus leavigata L., i Prunus spinosa L, in the stage of full maturity, in the region of southeast Serbia in July 2010. The study area is located in the surroundings of the city of Nis, which has about 300,000 inhabitants and is the third-largest city in the country after Belgrade and Novi Sad. However, the industry in this area is poorly developed. Sample sites were selected in accordance with the methods used in the European moss monitoring project [19]. A minimum distance of $300 \mathrm{~m}$ to major roads and larger settlements was required, as well as a minimum distance of $100 \mathrm{~m}$ to minor roads and houses and a minimum distance of $5 \mathrm{~m}$ to forest roads. Plants were first washed with distilled water and then dried at a temperature of $105{ }^{\circ} \mathrm{C}$ for $24 \mathrm{~h}$. The herbs materials were then homogenized.

\section{Procedures}

Mineralization. The standard procedure described by the Association of Official Analytical Chemists (AOAC) was followed for the preparation of the samples for the analysis of heavy metals [20]. Accurately weighed (1 g) sample was transferred into a silica crucible and kept in a muffle furnace for ashing at $450{ }^{\circ} \mathrm{C}$ for $3 \mathrm{~h}$ and then $5 \mathrm{ml}$ of $6 \mathrm{M} \mathrm{HCl}$ was added to the crucible. Care was taken to ensure that all the ash came into contact with acid. Further, the crucible containing acid solution was kept on a hot plate and digested to obtain a clean solution. The final residue was dissolved in $0.1 \mathrm{M} \mathrm{HNO}_{3}$ solution and made up to $25 \mathrm{ml}$. Working standard solutions were prepared by diluting the stock solution with $0.1 \mathrm{M}$ nitric acid for checking the linearity.

Preparation of water extracts. The two methods commonly used for preparation of water extracts were applied for this study, in order to assess the actual amount of heavy metal reach human body trough drinking such beverages.

\section{Method I}

Brew. In this method, $2 \mathrm{~g}$ of herb was boiled with $100 \mathrm{ml}$ of destiled water for $5 \mathrm{~min}$. The mixture was held for $5 \mathrm{~min}$ at room temperature and then filtered. After that, $2.5 \mathrm{ml} \mathrm{HCl}: \mathrm{H}_{2} \mathrm{O}(1: 1)$ and $2.5 \mathrm{ml} \mathrm{HNO}: \mathrm{H}_{2} \mathrm{O}$ (1:1) were added. The thus obtained solution was used for the analysis of heavy metals.

\section{Method II}

Infusion. In this method, $100 \mathrm{ml}$ of hot destilled water was added to $2 \mathrm{~g}$ of herb. The mixture was left to cool at room temperature for $5 \mathrm{~min}$ and then filtered to obtain a clear solution for futher procesing.

\section{Statistical analysis}

The data were reported as mean \pm standard deviation (SD) for triplicate determinations. Significance of inter-group differences was determined by the analysis of variance (ANOVA). A p value of less than 0.05 was considered statistically significant.

\section{RESULTS AND DISCUSION}

Contents of metals in medicinal plants are shown in Table 3. Metals are accumulated from the soil on which the plants were grown, especially Fe, followed by $\mathrm{Mn}$, $\mathrm{Zn}$, and $\mathrm{Cu}$.

The iron concentration in the investigated plant samples was the highest and ranged from 65.3 to 490.6 $\mathrm{mg} / \mathrm{kg}$. The contents of zinc, manganese, and copper in herbs varied from 11.8 to $32.3 \mathrm{mg} / \mathrm{kg}$ for zinc, from 6.00 to $46.64 \mathrm{mg} / \mathrm{kg}$ for manganese, and from 13.0 to $46.5 \mathrm{mg} / \mathrm{kg}$ for copper. The contents of non-essential heavy metals, $\mathrm{Pb}, \mathrm{Ni}$ and $\mathrm{Cd}$ was exceptionally low in herbs, decreasing in the following order: $\mathrm{Pb}$ (7.8-0.1 $\mathrm{mg} / \mathrm{kg})>\mathrm{Ni}(2.0-4.0 \mathrm{mg} / \mathrm{kg})>\mathrm{Cd}(0.6-1.8 \mathrm{mg} / \mathrm{kg})$.

The $\mathrm{Cd}$ and $\mathrm{Ni}$ concentration in water extracts prepared by methods I and II was too low to be detected by AAS. Lead concentrations in investigated water extract were very low and amounted from 2.3 to $6.1 \mathrm{mg} / \mathrm{kg}$ (method I), and from 3.0 to $8.4 \mathrm{mg} / \mathrm{kg}$ (method II). On the other hand, the contents of essential metals ( $\mathrm{Fe}, \mathrm{Mn}, \mathrm{Zn}$ and $\mathrm{Cu}$ ) in the investigated water extracts were relatively high.

Concentration of Fe in beverages prepared according to method I was from 11.1 to $42.1 \mathrm{mg} / \mathrm{kg}$, and in

Table 2. Analytical characteristics of the AAS determination

\begin{tabular}{lccccc}
\hline Element & Working range, $\mathrm{mg} / \mathrm{l}$ & LOD $/ \mathrm{mg} \mathrm{I}^{-1}$ & Wavelength, $\mathrm{nm}$ & Slit & Correlation coefficient \\
\hline $\mathrm{Fe}$ & $0.00-10.00$ & 0.015 & 248.3 & 0.2 & 0.9987 \\
$\mathrm{Cu}$ & $0.00-1.00$ & 0.007 & 213.9 & 1.0 & 0.9999 \\
$\mathrm{Zn}$ & $0.00-5.00$ & 0.021 & 324.8 & 0.5 & 0.9990 \\
$\mathrm{~Pb}$ & $0.00-1.00$ & 0.002 & 217.0 & 1.0 & 0.9993 \\
$\mathrm{Cd}$ & $0.00-1.00$ & 0.003 & 228.8 & 0.5 & 0.9991 \\
$\mathrm{Mn}$ & $0.00-2.00$ & 0.005 & 279.5 & 0.2 & 0.9987 \\
$\mathrm{Ni}$ & $0.00-1.00$ & 0.002 & 232.0 & 0.2 & 0.9994 \\
\hline
\end{tabular}


Table 3. Concentration of metals ( $\mathrm{mg} / \mathrm{kg}$ dry mass, mean of three values) in medicinal plants and their water extracts

\begin{tabular}{llccccccc}
\hline Plant & & $\mathrm{Zn}$ & $\mathrm{Mn}$ & $\mathrm{Fe}$ & $\mathrm{Pb}$ & $\mathrm{Ni}$ & $\mathrm{Cu}$ & $\mathrm{Cd}$ \\
\hline Hipericum perforatum L. Plant & $32.2 \pm 0.6$ & $33.3 \pm 1.0$ & $65.3 \pm 2.0$ & $7.8 \pm 0.2$ & $3.0 \pm 0.1$ & $21.8 \pm 0.4$ & $0.8 \pm 0.1$ \\
& Method I & $28.0 \pm 0.6$ & $15.2 \pm 0.5$ & $13.0 \pm 0.4$ & $2.6 \pm 0.1$ & - & $5.1 \pm 0.1$ & - \\
& Method II & $26.2 \pm 0.5$ & $12.0 \pm 0.4$ & $10.1 \pm 0.3$ & $3.1 \pm 0.1$ & - & $3.1 \pm 0.1$ & - \\
Saturea Montana L. & Plant & $31.0 \pm 0.6$ & $28.3 \pm 0.9$ & $156.8 \pm 4.7$ & $16.6 \pm 0.3$ & $2.5 \pm 0.1$ & $28.8 \pm 0.6$ & $1.8 \pm 0.1$ \\
& Method I & $25.2 \pm 0.5$ & $11.2 \pm 0.3$ & $17.6 \pm 0.5$ & $3.8 \pm 0.1$ & - & $1.1 \pm 0.1$ & - \\
& Method II & $18.1 \pm 0.4$ & $7.1 \pm 0.2$ & $12.4 \pm 0.4$ & $4.4 \pm 0.1$ & - & $0.9 \pm 0.1$ & - \\
Calendula officinalis L. & Plant & $31.5 \pm 0.6$ & $33.3 \pm 1.0$ & $490.6 \pm 14.7$ & $9.8 \pm 0.2$ & $4.0 \pm 0.1$ & $46.5 \pm 0.9$ & $0.8 \pm 0.1$ \\
& Method I & $28.0 \pm 0.6$ & $14.0 \pm 0.4$ & $42.0 \pm 1.3$ & $3.1 \pm 0.1$ & - & $10.1 \pm 0.2$ & - \\
Origanum vulgare L. & Method II & $21.1 \pm 0.4$ & $12.4 \pm 0.4$ & $25.2 \pm 0.6$ & $3.1 \pm 0.1$ & - & $9.0 \pm 0.2$ & - \\
& Plant & $17.1 \pm 0.3$ & $46.6 \pm 1.4$ & $93.7 \pm 2.9$ & $20.1 \pm 0.4$ & $2.0 \pm 0.1$ & $23.1 \pm 0.5$ & $0.6 \pm 0.1$ \\
& Method I & $12.1 \pm 0.2$ & $27.5 \pm 0.8$ & $11.1 \pm 0.3$ & $6.1 \pm 0.1$ & - & $3.1 \pm 0.1$ & - \\
Crataegus leavigata L. & Mlant & $11.8 \pm 0.2$ & $6.0 \pm 0.2$ & $119.4 \pm 3.6$ & $8.3 \pm 0.2$ & $2.4 \pm 0.1$ & $13.2 \pm 0.3$ & $0.8 \pm 0.1$ \\
& Method I & $8.2 \pm 0.2$ & $3.0 \pm 1.0$ & $28.1 \pm 0.8$ & $2.5 \pm 0.1$ & - & $3.0 \pm 0.1$ & - \\
Prunus spinosa L. & Method II & $5.04 \pm 0.1$ & $2.5 \pm 0.1$ & $25.6 \pm 0.8$ & $3.0 \pm 0.1$ & - & $2.9 \pm 0.1$ & - \\
& Plant & $14.5 \pm 0.3$ & $9.5 \pm 0.3$ & $130.8 \pm 3.9$ & $8.8 \pm 0.2$ & $3.2 \pm 0.1$ & $13.0 \pm 0.3$ & $0.8 \pm 0.1$ \\
& Method I & $9.5 \pm 0.2$ & $4.6 \pm 0.1$ & $15.4 \pm 0.5$ & $2.3 \pm 0.1$ & - & $2.6 \pm 0.1$ & - \\
& Method II & $6.9 \pm 0.1$ & $3.9 \pm 0.1$ & $14.0 \pm 0.4$ & $3.0 \pm 0.1$ & - & $2.1 \pm 0.1$ & - \\
\hline
\end{tabular}

those prepared according to method II from 8.95 to $25.60 \mathrm{mg} / \mathrm{kg}$. Zinc concentration varied in the range from 8.15 to $28.02 \mathrm{mg} / \mathrm{kg}$ (method I), and from 5.05 to $26.15 \mathrm{mg} / \mathrm{kg}$ (method II).

Manganese concentration was from 3.0 to 27.5 $\mathrm{mg} / \mathrm{kg}$ (method I), while for method II it amounted from 2.5 to $24.1 \mathrm{mg} / \mathrm{kg}$. In herbal extracts, copper had the lowest content, and varied from 2.6 to $10.1 \mathrm{mg} / \mathrm{kg}$ (method I), and from 2.0 to $9.0 \mathrm{mg} / \mathrm{kg}$ (method II).

The contents of heavy metals in water extracts prepared by method I and method II decreased in the following order: $\mathrm{Fe}>\mathrm{Zn}>\mathrm{Mn}>\mathrm{Cu}>\mathrm{Pb}$. Metal concentrations in beverages prepared by method I were slightly higher. Only the concentration of $\mathrm{Pb}$ was higher in beverages prepared by method II.
The heavy metals concentrations in water extracts prepared by medicinal plants are affected by numerous factors, such as: organic matter contained in individual herbs that can chelate heavy metals, solubility of mineral and organic matter in water, minerals content and $\mathrm{pH}$ value of the water used for the preparation of extracts. In order to avoid the influence of water quality on the heavy metals concentration in the extracts, demineralized water was used for their preparation.

The extraction coefficient of the investigated metals was calculated as the relation between the metal concentration in the herbal beverages and the total metal content in the herb.

As seen in Table 4, the extraction coefficients vary in the range from 3.27 to $88.86 \%$. Based on the

Table 4. Extraction coefficients (\%) of metals

\begin{tabular}{|c|c|c|c|c|c|c|}
\hline Plant & Water extracts & $\mathrm{Zn}$ & $\mathrm{Mn}$ & $\mathrm{Fe}$ & $\mathrm{Pb}$ & $\mathrm{Cu}$ \\
\hline \multirow[t]{2}{*}{ Hipericum perforatum L. } & Method I & 86.90 & 47.74 & 19.98 & 33.55 & 23.22 \\
\hline & Method II & 81.05 & 36.12 & 15.51 & 40.13 & 14.34 \\
\hline \multirow[t]{2}{*}{ Saturea Montana L. } & Method I & 81.31 & 39.40 & 11.25 & 23.02 & 3.83 \\
\hline & Method II & 58.42 & 24.98 & 7.90 & 26.59 & 3.27 \\
\hline \multirow[t]{2}{*}{ Calendula officinalis L. } & Method I & 88.86 & 42.19 & 8.57 & 31.69 & 21.63 \\
\hline & Method II & 66.86 & 37.29 & 5.14 & 31.79 & 19.39 \\
\hline \multirow[t]{2}{*}{ Origanum vulgare L. } & Method I & 70.70 & 59.00 & 11.43 & 30.54 & 13.43 \\
\hline & Method II & 46.78 & 51.73 & 9.26 & 56.90 & 11.09 \\
\hline \multirow[t]{2}{*}{ Crataegus leavigata $L$. } & Method I & 69.36 & 50.17 & 23.53 & 33.94 & 22.64 \\
\hline & Method II & 42.89 & 41.67 & 21.44 & 36.36 & 21.58 \\
\hline \multirow[t]{2}{*}{ Prunus spinosa L. } & Method I & 61.95 & 48.32 & 11.81 & 25.83 & 19.85 \\
\hline & Method II & 47.38 & 40.97 & 10.68 & 34.17 & 15.69 \\
\hline
\end{tabular}


obtained results of the extraction coefficient, the analyzed elements can be classified into three groups: those with a low extraction coefficient (less than 20\%) - Fe and $\mathrm{Cu}$; elements with a medium extraction coefficient $(20-60 \%)-\mathrm{Pb}$ and $\mathrm{Mn}$, and elements with the extraction coefficient higher than $60 \%-\mathrm{Zn}$. The extraction coefficients of the investigated metals can be presented in the declining order: $\mathrm{Fe}>\mathrm{Zn}>\mathrm{Mn}>\mathrm{Cu}>\mathrm{Pb}$.

The data from Table 3 indicate a great transfer of metals, which is higher in herbal beverages prepared with method I ( $\mathrm{Pb}$ being the only exception in this case). The obtained results are in accordance with those obtained by Abou-Arab et al. [13].

Correlation coefficients of heavy metals content in medicinal plants and their water extracts were also determined. The correlation coefficients of heavy metals contents in plants and their extracts (given in Table 4) were calculated using the following equation [14]:

$R=\frac{\sum_{i}\left(x_{i}-\bar{x}\right)\left(y_{i}-\bar{y}\right)}{\sqrt{\sum_{i}\left(x_{i}-\bar{x}\right)^{2} \sum_{i}\left(y_{i}-\bar{y}\right)^{2}}}$

The values of correlation coefficients existed between the metals content (mean value of three measurements) in medicinal plants and their water extracts prepared by method I were: Fe (0.8853), Zn (0.9956), $\mathrm{Mn}(0.9586)$, and $\mathrm{Pb}(0.8680)$ and $\mathrm{Cu}(0.7924)$.

A significant correlation also existed between the metals content in medicinal plants and their water extracts prepared by method II, amounting to: Zn (0.9650), $\mathrm{Mn}(0.9255), \mathrm{Pb}(0.9384), \mathrm{Fe}(0.6370)$ and $\mathrm{Cu}$ (0.7693) (Table 5).

Table 5. Correlation coefficients between the concentrations of metals in medicinal plants and their water extracts

\begin{tabular}{lccccc}
\hline \multirow{2}{*}{ Method } & \multicolumn{5}{c}{ Metal } \\
\cline { 2 - 6 } & $\mathrm{Zn}$ & $\mathrm{Mn}$ & $\mathrm{Fe}$ & $\mathrm{Pb}$ & $\mathrm{Cu}$ \\
\hline $\mathrm{I}$ & 0.9956 & 0.9586 & 0.8853 & 0.8680 & 0.7924 \\
$\mathrm{II}$ & 0.9650 & 0.9255 & 0.6370 & 0.9384 & 0.7693 \\
\hline
\end{tabular}

A number of authors from various countries have determined the content of heavy metals in different plants and their extracts.

Table 6 shows the survey of metals contents in various plants from various regions. A conclusion can be drawn that there are significant differences in the heavy metals contents in the investigated plants, which can be a consequence of different soil quality on which the plants had been grown, having in mind the geographical distances between the regions on one hand, and on the other hand, the ability of the plants species themselves to accumulate the individual heavy metals. It is well known that some plants have an extraordinary ability to accumulate heavy metals and are used for bioremediation of the soil.

When the results of heavy metals contents in the investigated extracts are compared with those of other authors, the accordance level is slightly lower regarding the absolute heavy metals concentration, while the accordance is higher with respect to extraction coefficients.

Based on the data on heavy metals contents in plant extracts from various regions (Table 7), one can recognize that the results are very much congruent with the exception of Thailand, where the extracts have very high values for $\mathrm{Mn}$, and Egypt with very high values for $\mathrm{Zn}$ and $\mathrm{Mn}$. These can be a consequence of the geochemical composition of the soil where the plants have been grown, causing a high content of these metals in the plant materials and, consequently, in their water extracts. The accordance is significantly higher with respect to the extraction coefficient and coefficient of correlation between the heavy metals content in medicinal plants and their water extracts.

A comparative study of the results of heavy metals content in medicinal plants and their water extracts (Table 3) with recommended daily intake of elements for an adult person (Table 1) we can see that herbal teas can represent a good source of essential elements. However, their use should be under strict control because of possible presence of toxic elements, such as

Table 6. Comparison of metal contents ( $\mathrm{mg} / \mathrm{kg}$ dry mass) of Serbian medicinal plants with other plants from different areas

\begin{tabular}{lcccccccc}
\hline State & $\mathrm{Zn}$ & $\mathrm{Mn}$ & $\mathrm{Fe}$ & $\mathrm{Pb}$ & $\mathrm{Ni}$ & $\mathrm{Cu}$ & $\mathrm{Cd}$ & Reference \\
\hline Serbia & $11.75-32.25$ & $6.00-46.61$ & $65.25-490.62$ & $7.75-20.07$ & $1.97-3.95$ & $13.0-46.5$ & $0.62-1.75$ & Present study \\
Serbia & $31-34$ & $106-111$ & - & $4.5-5.5$ & $27-58$ & $19-22$ & $0.5-0.75$ & {$[24]$} \\
Serbia & $15.0-43.0$ & $25.0-111.0$ & $75.0-546$ & - & - & $5.92-14.79$ & - & {$[5]$} \\
Pakistan & $55.3-70$ & $24.6-28.9$ & $125.2-151.1$ & - & - & $12.2-14.3$ & - & {$[23]$} \\
Pakistan & $17.38-65.85$ & $34.14-105.56$ & $181.63-6796.88$ & $3.15-10.63$ & $2.6-15.8$ & $7.06-19.19$ & $0.59-1.66$ & {$[25]$} \\
India & - & - & - & $0.48-1.03$ & $1.1-5.3$ & $15.9-32.2$ & $0.05-0.38$ & {$[18]$} \\
Iran & - & - & - & $2.08-2.59$ & - & $17.59-32.8$ & - & {$[27]$} \\
Egypt & $8-68.8$ & $9.8-289$ & $26.96-1046$ & $0.5-14.4$ & $0.61-2.85$ & $1.8-11.4$ & $1.06-2.44$ & {$[21]$} \\
Turkey & $21.9-48.4$ & $23-244$ & $224.8-810$ & $0.26-4.80$ & $0.90-5.4$ & $3.92-35.8$ & $0.004-0.44$ & {$[11]$} \\
Ethiopia & $20.2-21.6$ & $1242-1421$ & $319-467$ & - & - & $9.1-11.5$ & - & {$[1]$} \\
\hline
\end{tabular}


Table 7. Comparison of metal contents ( $\mathrm{mg} / \mathrm{kg} \mathrm{d.w.)} \mathrm{in} \mathrm{extracts} \mathrm{prepared} \mathrm{from} \mathrm{Serbian} \mathrm{medicinal} \mathrm{plants} \mathrm{and} \mathrm{plant} \mathrm{extracts} \mathrm{from}$ different areas

\begin{tabular}{|c|c|c|c|c|c|c|}
\hline Area & $\mathrm{Zn}$ & $\mathrm{Mn}$ & $\mathrm{Fe}$ & $\mathrm{Pb}$ & $\mathrm{Cu}$ & Reference \\
\hline Serbia & $8.15-28.2$ & $3.01-27.05$ & $11.05-42.05$ & $0.37-4.67$ & $2.58-10.6$ & This paper \\
\hline Thailand & $1.37-29.77$ & $4.79-370.85$ & $2.22-29.77$ & - & $12.2-14.3$ & {$[12]$} \\
\hline Turkey & $3.9-18.0$ & - & $2.45-107.4$ & - & $2.45-8.10$ & {$[11]$} \\
\hline Egypt (spice and medicinal plants) & $30.56-112.45$ & $130.77-220$ & $30.56-122.45$ & - & $3.34-20.12$ & {$[28]$} \\
\hline Egypt (tea) & $5.5-48.25$ & - & - & $0.37-4.65$ & $1.05-9.15$ & {$[21]$} \\
\hline Iran & - & - & - & - & $1.15-1.65$ & [27] \\
\hline
\end{tabular}

$\mathrm{Pb}$ and $\mathrm{Cd}$. Nevertheless, values given in Table 3 are the concentrations of elements in plants and water extracts given for $1 \mathrm{~kg}$ of any medicinal herb per day. Having in mind that the medicinal herbs are packed in bags containing averagely $2 \mathrm{~g}$ of plant material, that means that only $10 \mathrm{~g}$ of any plant is used if the herbal tea is consumed five times per day. Consequently, there is no danger from toxic elements originating from the herbal tea.

\section{CONCLUSION}

Metal contents in medicinal plants from the region of southeast Serbia (Hypericum perforatum L., Saturea montana L., Calendula officinalis L., Origanum vulgare L., Crataegus laevigata L., and Prunus spinosa L.) and water extracts prepared from them by two methods were investigated by AAS. In medicinal plants founded the presence of the following metals: Fe, $\mathrm{Zn}, \mathrm{Mn}, \mathrm{Cu}$, $\mathrm{Pb}, \mathrm{Cd}$ and $\mathrm{Ni}$, and their concentration was determined The contents of metals in the herbal beverages, regardless of the preparation method, were significantly lower than their concentration in the herbs and decreased in this order: $\mathrm{Fe}>\mathrm{Zn}>\mathrm{Mn}>\mathrm{Cu}>\mathrm{Pb}$. The contents of $\mathrm{Ni}$ and $\mathrm{Cd}$ were below the detection limit and were not possible to determine by the AAS method. It was found that the extract preparation method had an effect on the heavy metals content. Contents of investigated metals in both water extracts were markedly lower then in medicinal plants, but higher in water extract prepared by method (I), with exception of lead content. Accordingly, the extraction coefficients varied in the range from 0.0 to $88.86 \%$.

Correlation analysis by ANOVA statistical program proved that there is great transfer of metals from the herbs into the herbal beverages. The correlation coefficients of heavy metals contents in the herbs and their beverages are very high and amount from 0.6369 to 0.9956 .

The results represent a significant contribution to the study of metal content in medicinal plants, transferring them to the water extracts and the potential effect on human health as a result of their consumption. The investigated medicinal plants and their water extracts can be safely used in food, in terms of metal content.

\section{Acknowledgements}

This work was supported under the projects No.Ol 172047 by the Ministry of Education, Science and Technological Development of the Republic of Serbia.

\section{REFERENCES}

[1] D. W. Gebretsadik, B. S. Chandravanshi, Levels of metals in commercially available Ethiopian black teas and their infusion, Bull.Chem.Soc.Ethiop. 24 (3) (2010), 339-349.

[2] Lenntech B.V, http://www.lenntech.com/recommended-daily-intake.htm\#ixzz27P3CVWjr (accessed on 3.9.2013).

[3] T. Karak, R.M. Bhagat, Trace elements in tea leaves, made tea and tea infusion: A Review, Food Res. Int. 43 (2010) 2234-2252.

[4] S. Ražić, A. Onja, B. Potkonjak, Trace elements analysis of Echinacea purpurea - herbal medicinal, J. Pharmaceut. Biomed. 33 (2003) 845-850.

[5] S. Ražić, A. Onja, S. Đogo, L. Slavković, A. Popović, Determination of metal content in some herbal drugsEmpirical and chemometric approach, Talanta 67 (2005) 233-239.

[6] S. Ražić, A. Onjia, S. Đogo, L. Slavković, Inorganic analysis of herbal drugs. Part I. Metal determination in herbal drugs originating from medicinal plants of the family Lamiacae, J.Serb.Chem.Soc. 70(11) (2005) 1347-1355.

[7] S. Ražić, S. Đogo, L. Slavković, Multivariate characterization of herbal drugs and rhizosphere soil samples according to their metallic content, Microchem. J. 84(1-2) (2006) 93-101.

[8] S. Ražić, S. Đogo, L. Slavković, Inorganic analysis of herbal drugs. Part II. Plant and soil analysis - diverse bioavailability and uptake of essential and toxic elements, J. Serb. Chem. Soc. 71(10) (2006) 1095-1105.

[9] A.Perić-Grujić, V. Pocajt, M. Ristić, Determination of Heavy Metal Concentrations In Tea Samples Taken From Belgrade Market, Serbia, Hem. Ind. 63 (2009) 433-436.

[10] D. Kostic, S. Mitic, A. Zarubica, M.Mitic, J. Velickovic, S. Randjelovic, Determination of trace metals in medicinal plants and their extracts, Hem. Ind. 65 (2) (2010) 165-170 .

[11] S. Basgel, S. B. Erdemoglu, Determination of mineral and trace elements in some medicinal herbs and their 
infusions consumed in Turkey, Sci. Total Environ. 359 (2006) 82-89.

[12] S. Nookabkaew, N. Rangkadilok, J. Satayavivad, Determination of Trace Elements in Herbal Tea Products and Their Infusions Consumed in Thailand, J. Agric. Food Chem. 54 (2006) 6939-6944.

[13] S. Kasper, Hypericum perforatum - a review of clinical studies. Pharmacopsychiatry 34 (2001) 51-55.

[14] V. Slavkovska, R. Jancic, S. Bojovic, S. Milosavljevic, D. Djokovic, Variability of essential oils of Satureja montana L. and Satureja kitaibelii wierzb. Ex Heuff. from the central part of the Balkan peninsula. Phytochemistry $\mathbf{5 7}$ (2001) 71-76.

[15] A. Raal, K. Kirsipuu, Total flavonoid content in varieties of Calendula officinalis L. originating from different countries and cultivated in Estonia, Nat. Prod. Res. 25 (2011) 658-662.

[16] B. M. Lawrence, The botanical and chemical aspects of oregano, Perfum. Flavor 9 (1984) 41-52.

[17] World Health Organization (WHO). Monographs on selected medicinal plants, Folium cum Flore Crataegi, Vol. 2, World Health Organization (WHO), Geneva, 2002, p. 66.

[18] K. Browics, Prunus, In: Davis P.H. (ed.), Flora of Turkey and East Eagean Islands. Vol 4. University Press, Edinburgh, 1972, pp. 8-12.

[19] H. G. Zechmeister, D. Hohenwallner, A. Riss, A. HanusIllnar, Variations in heavy metal concentrations in the moss species Abietinella abietina (Hedw.) Fleisch. According to sampling time, within site variability and increase in biomass, Sci. Total. Environ. 301 (2003) 55-65 .
[20] A.O.A.C. 2000, Official Methods of Analysis, Association of Official Analytical Chemist, EUA.

[21] A.K. Abou-Arab, M.A. Abou Donia, Heavy metals in Egyptian spicies and medicinal plants and the effect of processing on their levels, J. Agric. Food Chem 48 (2000) 2300-2304.

[22] Stats Tutorial, University of Toronto, http:// //www.chem.utoronto.ca/coursenotes/analsci/StatsTut orial/CorrCoeff.html (Accessed on 3.9.2013).

[23] J. Pirzada, W. Shaikh, K.U. Ghani,. K.A. Laghari, Study of anti fungal activity and some basic elements of medicinal plant cressa cretica linn against fungi causing skin diseases, Sindh Univ. Res. Jour. (Sci. Ser.). 41(2) (2009) $15-20$.

[24] D. Radanović, S. Antić Mladenović, M. Jakovljević, M. Kresović, Content of heavy metals in Gentiana lutea L. roots and galenic forms, J. Serb. Chem. Soc. 72(2) (2007) 133-138.

[25] S. Jabeen, M. Tahir Shah, S. Khan, M. Qasim Hayat, Determination of major and trace elements in ten important folk therapeutic plants of Haripur basin, Pakistan, J. Med. Plants Res. 4(7) (2010) 559-566.

[26] S. Seenivasan, N. Manikandan, N. N. Muraleedharan, R. Selvasundaram, Heavy metal content of black teas from south India, Food control. 19 (2008) 746-749.

[27] G. Karimi, M.K. Hasanzadeh, A. Nili, Z. Khashayarmanesh, Z. Samiei, F. Nazari, M. Teimuri, Concentrations and Health risk of heavy metals in tea samples marketed in Iran, Pharmacology 3 (2008) 164-174.

[28] Y.F. Lasheen, N.S. Awwad, A. El-Khalafawy, A.A. AbdelRassoul, Annual effective dose and concentration levels of heavy metals in different types of tea in Egypt, Int. J. of Phys. Sci. 3 (2008) 112-119.

\section{IZVOD}

\section{KORELACIONA ANALIZA SADRŽAJA METALA U LEKOVITIM BILKAMA I NJIHOVIM VODENIM EKSTRAKTIMA}

Sasa S. Ranđelović, Danijela A. Kostić, Aleksandra R. Zarubica, Snežana S. Mitić, Milan N. Mitić

Univerzitet u Nišu, Prirodno-matematički fakultet, Department za hemiju, Višegradska 33, 18000 Niš, Srbija

(Stručni rad)

Kvalitet biljaka i njihovih vodenih ekstrakata sa područja Jugoistočne Srbije odredjen je na osnovu sadržaja metala korišćenjem atomske absorpcione spektrometrije. Korišćene su dve metode za pripremu vodenih ekstrakata, kako bi se ispitao uticaj pripreme na sadržaj metala u njima. U vodenim ekstraktima sadržaj metala je niži od sadržaja u biljkama, ali u vodenom ekstraktu pripremljenom sa toplom vodom (metod I) koncentracije metala su veće, sa izuzetkom sadržaja olova. Ekstrakcioni koeficijenti posmatranih teški metala mogu biti predstavljni sledećim redosledom: $\mathrm{Zn}>\mathrm{Mn}>\mathrm{Pb}>\mathrm{Cu}>$ Fe. Korelacionom analizom su utvrđeni korelacioni koeficijenti između koncentracije teških metala u biljkama i njihovim ekstraktima i kreću se u granicama od 0,6369 do 0,9956. S obzirom na to neophodno je da se lekovito bilje gaji i bere na nezagadjenom području, i da se ispituje sadržaj metala. Sadržaj metala u ispitivanim biljkama i njihovim vodenim ekstraktima je ispod maksimalno dozvoljene vrednosti, tako da su bezbedni za korišćenje.
Ključne reči: Lekovito bilje • Vodeni ekstrakti • AAS 